\title{
Alkaline Phosphatases in the Complex Chronic Kidney Disease-Mineral and Bone Disorders
}

\author{
Jordi Bover $^{1}$ • Pablo Ureña ${ }^{2} \cdot$ Armando Aguilar $^{1} \cdot$ Sandro Mazzaferro $^{3} \cdot$ Silvia Benito $^{1}$ • Víctor López-Báez ${ }^{1}$. \\ Alejandra Ramos ${ }^{1} \cdot$ lara daSilva $^{1} \cdot$ Mario Cozzolino $^{4}$
}

Received: 29 November 2017 / Accepted: 29 January 2018

(c) Springer Science+Business Media, LLC, part of Springer Nature 2018

\begin{abstract}
Alkaline phosphatases (APs) remove the phosphate (dephosphorylation) needed in multiple metabolic processes (from many molecules such as proteins, nucleotides, or pyrophosphate). Therefore, APs are important for bone mineralization but paradoxically they can also be deleterious for other processes, such as vascular calcification and the increasingly known cross-talk between bone and vessels. A proper balance between beneficial and harmful activities is further complicated in the context of chronic kidney disease (CKD). In this narrative review, we will briefly update the complexity of the enzyme, including its different isoforms such as the bone-specific alkaline phosphatase or the most recently discovered B1x. We will also analyze the correlations and potential discrepancies with parathyroid hormone and bone turnover and, most importantly, the valuable recent associations of AP's with cardiovascular disease and/or vascular calcification, and survival. Finally, a basic knowledge of the synthetic and degradation pathways of APs promises to open new therapeutic strategies for the treatment of the CKD-Mineral and Bone Disorder (CKD-MBD) in the near future, as well as for other processes such as sepsis, acute kidney injury, inflammation, endothelial dysfunction, metabolic syndrome or, in diabetes, cardiovascular complications. However, no studies have been done using APs as a primary therapeutic target for clinical outcomes, and therefore, AP's levels cannot yet be used alone as an isolated primary target in the treatment of CKD-MBD. Nonetheless, its diagnostic and prognostic potential should be underlined.
\end{abstract}

Keywords Alkaline phosphatase · Bone alkaline phosphatase $\cdot$ CKD $\cdot$ CKD-MBD $\cdot$ Pyrophosphate $\cdot$ Vascular calcification $\cdot$ Survival

Jordi Bover

jbover@fundacio-puigvert.es

1 Department of Nephrology, Fundació Puigvert, IIB Sant Pau, RedinRen, C. Cartagena, Catalonia, 340-350 Barcelona, Spain

2 Department of Nephrology and Dialysis, Clinique du Landy and Department of Renal Physiology, Necker Hospital, University of Paris Descartes, Paris, France

3 Department of Cardiovascular, Respiratory, Nephrologic and Geriatric Sciences, Sapienza University of Rome, Rome, Italy

4 Laboratory of Experimental Nephrology, Renal Division,San Paolo Hospital, DiSS University of Milan, Milan, Italy

\section{Introduction}

Alkaline phosphatases (APs) are membrane-bound glycoprotein hydrolases responsible for removing phosphate (P) groups (dephosphorylation or P-ester hydrolysis) from many molecules (nucleotides, proteins...), most effectively operating in an alkaline environment [1] (Fig. 1). Thus, $\mathrm{P}$ becomes available for many processes not only such as bone mineralization but also, as we appreciated in recent years, vascular calcification. Circulating APs, particularly the tissue non-specific alkaline phosphatase (TNAP), may increase hydrolysis of pyrophosphate [2,3], a natural inhibitor of hydroxyapatite formation in the extracellular fluid. Indeed pyrophosphate, which physiologically comes from the hydrolysis of extracellular nucleotides (essentially ATP) by the enzyme ENPP1 (ectonucleotide pyrophosphatase phosphodiesterase type 1, to pyrophosphate and AMP) (Fig. 2), is a well-known potent inhibitor of vascular calcification since 


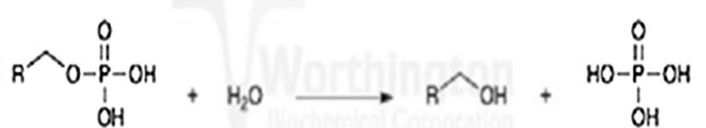

Phosphate monoester

Alcohol

Phosphate

Fig. 1 Alkaline phosphatase mediated reaction

it prevents the incorporation of inorganic $\mathrm{P}$ into hydroxyapatite crystals $[1,2,4]$. Consequently, the modulatory effect of APs on the balance between inorganic $\mathrm{P}$ and inorganic pyrophosphate seems to be involved in the increasingly recognized cross-talk between bone and vessels and the imbalance between bone mineralization and cardiovascular calcification [5-2]. This narrative review will briefly update the biochemical complexity of the enzyme, the correlations with parathyroid hormone (PTH) and bone turnover, and the most recent associations with survival, vascular calcification, and cardiovascular disease. Knowledge of the synthetic and degradation pathways of this enzyme promises to open new therapeutic perspectives, even beyond chronic kidney disease-mineral and bone disorders (CKD-MBD).

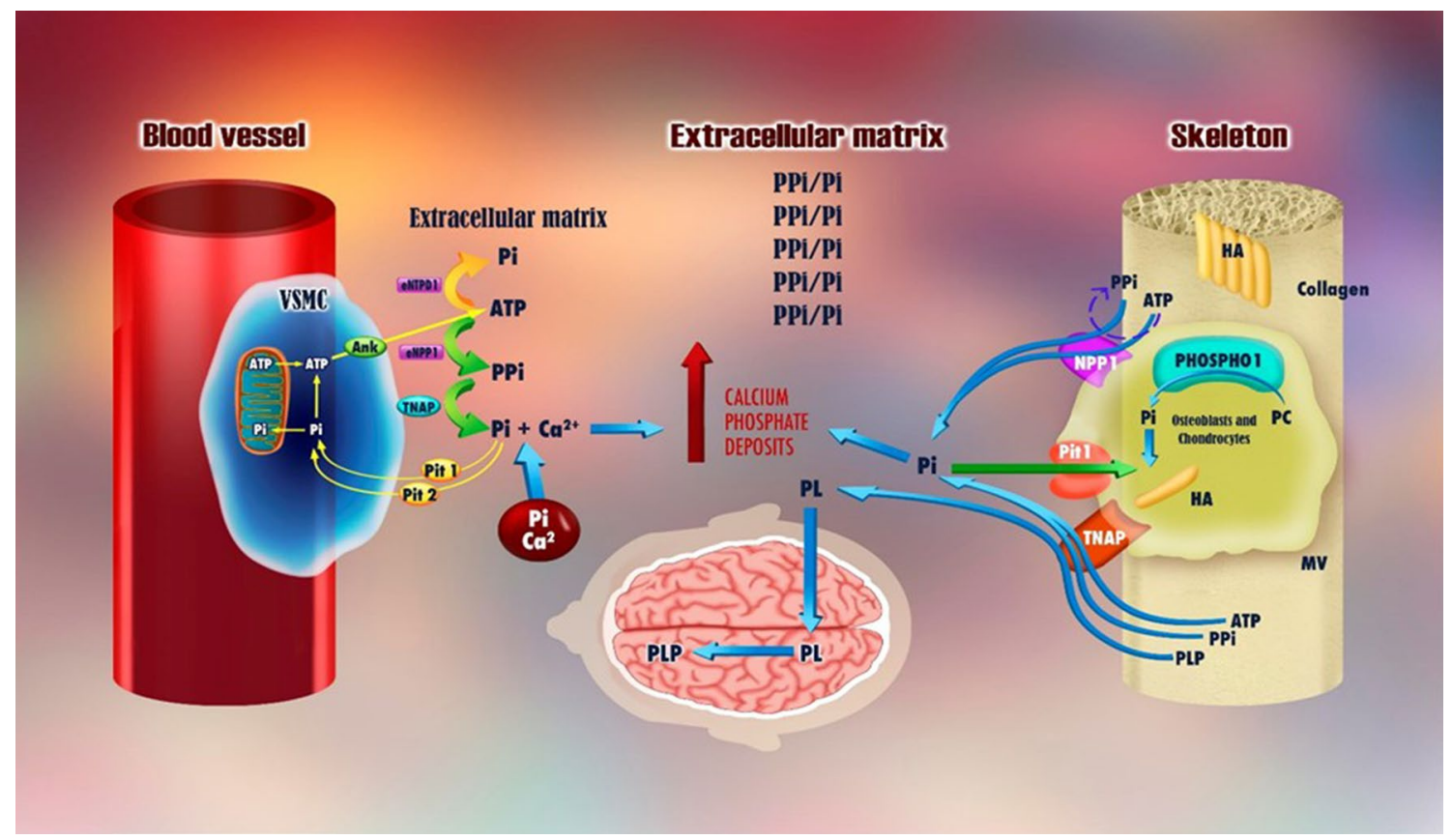

Fig. 2 Alkaline phosphatases in the relationship between vascular smooth muscle cells, extracellular matrix and skeleton. Left side: vascular smooth muscle cells (VSMC), from top to bottom: Apyrase1/ ectonucleoside triphosphatase diphosphohydrolase 1 (eNTPD1) is an important ectoenzyme for the synthesis of inorganic phosphate $\left(\mathrm{P}_{\mathrm{i}}\right)$ from adenosine triphosphate (ATP). On this same substrate acts the ectoenzyme nucleotide pyrophosphatase/phosphodiesterase-1 (eNPP1), but promoting the synthesis of pyrophosphate $\left(\mathrm{PP}_{\mathrm{i}}\right)$, so that ATP is a substrate of both ectoenzymes. ATP comes from the intracellular space by the action of several transporters such as the transmembrane protein (Ank) which is the product expression of the ankylosis gene. High extracellular ATP levels are related with pathological calcification [165]. Tissue-nonspecific alkaline phosphatase (TNAP) hydrolyzes extracellular $\mathrm{PP}_{\mathrm{i}}$ to $\mathrm{P}_{\mathrm{i}}$, which can then enter the VSMC by transporters Pit- 1 and Pit- 2 . Once inside the cell, $\mathrm{P}_{\mathrm{i}}$ can be taken up by the mitochondria and form new ATP molecules through oxidative phosphorylation. However, higher concentrations of $\mathrm{P}_{\mathrm{i}}$ within the VSMC also promote cellular transformation to a bone-forming cell phenotype, overexpressing osteochondrogenic transcription markers. On the other hand, the $\mathrm{P}_{\mathrm{i}}$ that does not enter the cell increases the tissue deposits of calcium and $\mathrm{P}_{\mathrm{i}}$ promoting tissue calcification. Right side: Bone cells. Mineralization of hydroxyapatite (HA) seems to be initiated both by the accumulation of iP generated inside the cell by the action of Phospho-1 [phosphoethanolamine/phosphocholine (PC) phosphatase] and the $\mathrm{P}_{\mathrm{i}}$ transported from the extracellular space by Pit-1. Extracellular $\mathrm{P}_{\mathrm{i}}$ concentrations depend on the action of: (a) NPP1, which normally stimulates extracellular $\mathrm{PP}_{i}$ synthesis but, under conditions of low expression of TNAP, promotes the synthesis of $\mathrm{P}_{\mathrm{i}}$ from both extracellular ATP and from $\mathrm{PP}_{\mathrm{i}}$ (like TNAP). (b) TNAP, which hydrolyzes both $\mathrm{PP}_{\mathrm{i}}$ and ATP to form $\mathrm{P}_{\mathrm{i}}$. This $\mathrm{P}_{\mathrm{i}}$ can either enter bone cells for appropriate use or it can be in blood where it will maintain the $\mathrm{PP}_{\mathrm{i}}-\mathrm{P}_{\mathrm{i}}$ ratio (one of the main determinants of vascular calcification and bone mineralization). As mentioned in the text, TNAP derives from several tissues and when refers to bone it is the bone-specific alkaline phosphatase (BSAP). Center: Central Nervous system (CNS). TNAP acts on Pyridoxal 5'-Phosphate (PLP). This is the major form of circulating vitamin B6 (metabolically active) and serves as a cofactor for at least 110 enzymes and as a coenzyme for the metabolism of several amino-acids (including those necessary for neurotransmitters (dopamine, serotonin, histamine, taurine and $\gamma$-aminobutyric acid). TNAP removes $P_{i}$ from the PLP molecule so that it becomes Pyridoxal (PL), one of the 7 forms of vitamin B6 and the only one that can enter in CNS cells, where PL is phosphorylated and converted back into PLP, becoming again the needed cofactor for a proper CNS functioning. Adapted from reference [161] 


\section{Total Alkaline Phosphatases and Bone-Specific Alkaline Phosphatase Isoenzymes}

Total AP includes two types of isoenzymes: tissue- and TNAPs. Tissue-specific APs are encoded by 3 genes and they derive from intestine, placenta, and stem-cells $[1,10]$, representing only about $5 \%$ of the total circulating APs. The TNAPs are encoded by a single gene and are present in several tissues, including liver, kidney, and bone, the last one referred to as bone-specific AP, BSAP, or BALP. Liver AP represents approximately $45 \%$ and BSAP $50 \%$ of total circulating APs but the exact mechanisms of AP release into the general circulation remain unclear.

BSAP is the generic term given to one of the enzymatic non-collagenous bone proteins [1] with a molecular weight of $80 \mathrm{kDa}$ and a relatively long half-life of 1.5-2.3 days, although it is lower than liver's (5-9 days). BSAP is a glycoprotein anchored to the membrane of osteoblasts and, as a by-product of osteoblast activity, it became a renowned and very specific bone formation marker [(such as osteocalcin and opposed to the bone resorption marker tartrate-resistant acid phosphatase (TRAP)] which we will review later. BSAP can bind to bone matrix proteins and induce bone mineralization through stimulation of pyrophosphate hydrolysis [1] (Fig. 2). BSAP isoforms may be distinguished by diverse posttranslational glycosylation type and extension, contributing to distinct catalytic properties [11].

\section{Relation Between Total APs, BSAP, PTH, and Bone Turnover}

Total AP has classically been associated with bone formation and generally regarded as a reliable marker of bone turnover in CKD [12, 13], provided that intact liver and biliary systems are present $[1,9]$. Less known is that hypervolemia or diastolic dysfunction in CKD (mainly dialysis patients) may increase total AP, probably by subclinical liver congestion and therefore not representing bone formation activity [14]. Moreover, one cannot always assume that if other hepatic enzymes (such as gamma-glutamyltransferase) are normal, increased total AP is from bone; thus, it has also been described that intestinal AP may be increased in hemodialysis patients [15-18]. Intestinal AP is an emerging field on clinical research as this AP isoenzyme has important functions in gut mucosal defense [19]. Total AP levels, as opposed to intact PTH (iPTH), are not affected by renal function [20].

On the other hand, BSAP is superior to total AP since BSAP is more sensitive and specific for bone disease, especially given the previously mentioned possible interference with liver isoenzymes, therefore becoming the most important marker for osteoblast differentiation [20, 21]. Furthermore, BSAP distinguishes better than both iPTH and total APs clinical situations of normal/low-turnover- from high-turnover-bone disease in dialysis patients [21]. Thus, it has been reported that $\mathrm{BSAP} \geq 20 \mathrm{ng} / \mathrm{ml}$, alone or combined with iPTH of $\geq 200 \mathrm{pg} / \mathrm{ml}$, had the highest sensitivity, specificity, and predictability values for the diagnosis of high-turnover bone disease and excluded patients with normal- or low-turnover-bone disease [20]. On the other side, several observations suggest that the diagnosis of lowturnover-bone disease in hemodialysis patients should be suspected when plasma iPTH levels are less than $150 \mathrm{pg} /$ $\mathrm{ml}$ and that BSAP levels are lower than $7 \mathrm{ng} / \mathrm{ml}$ (Ostase ${ }^{\circledR}$ method) [21, 22]. Coen et al. reported that, in 41 hemodialysis patients who underwent a bone biopsy, a plasma BSAP concentration lower than $12.9 \mathrm{ng} / \mathrm{ml}$ had a sensitivity of $100 \%$, a specificity of $94 \%$, and a positive predictive value of $72 \%$ in the prediction of low-turnover-bone disease [13]. Finally, in a recent prospective study of hemodialysis patients treated with calcimimetics with iPTH $\geq 300 \mathrm{pg} /$ $\mathrm{ml}$ (Advia Centaur) and BSAP $>20.9 \mathrm{ng} / \mathrm{ml}$ (Ostase $\left.{ }^{\circledR}\right)$, no bone-biopsy-based evidence of high-turnover bone disease was found in $17 \%$ of patients ( 22 normal, 3 mixed lesions), and no adynamic bone disease was present under these conditions [23]. A posterior cross-sectional retrospective diagnostic study found that BSAP was able to discriminate both low- from non-low and high- from non-high-bone-turnover disease analyzing 492 dialysis patients from Brazil, Portugal, Turkey, and Venezuela with a prior bone biopsy but without consideration of therapy [24]. In this study, the best cutoff for BSAP to discriminate low- from non-low-bone-turnover disease was $<33.1 \mathrm{U} / \mathrm{L}$ and for high- from non-high-boneturnover disease was $>42.1 \mathrm{U} / \mathrm{L}$ [24]. Importantly, serum BSAP was the only serum marker significantly higher among 137 dialysis patients with distal radius bone mineral density (BMD) reduction, including the sub-analysis of 42 diabetic patients with serum iPTH $<180 \mathrm{pg} / \mathrm{ml}$ (hypothetically low-bone-turnover state) [25]. Therefore, BSAP also seems to be a clinically useful bone formation marker to predict $\mathrm{BMD}$ reduction at least in diabetic dialysis patients with low circulating iPTH levels. A brief summary of the predictive value of intact PTH and BSAP in CKD patients is presented in Table 1.

\section{Discrepancies Between Parathyroid and Bone Activities}

Discrepancies between serum iPTH and BSAP levels, reflecting an uncoupling between bone resorption and formation, are uncommon but may be found in some patients $[20,26,27]$ (Table 2). Part of these discrepancies may be related to variability in the measurements of BSAP and iPTH. For instance, Delanaye et al. showed that there are large discrepancies in the variations of $\mathrm{PTTH}$ and BSAP concentrations over time in CKD-5D patients [28]. They also 
Table 1 Brief summary of the predictive value of intact PTH and BSAP in CKD patients

\begin{tabular}{|c|c|c|c|}
\hline Blood marker & $\begin{array}{l}\text { High-turnover sensitivity / speci- } \\
\text { ficity }\end{array}$ & Positive predictability & Study \\
\hline $\mathrm{BSAP}>20 \mathrm{ng} / \mathrm{mL}$ & $100 \% / 100 \%$ & $84 \%$ & Ureña-Torres P et al. [21] \\
\hline $\mathrm{BSAP}>15 \mathrm{ng} / \mathrm{mL}$ & $97 \% / 83 \%$ & $86 \%$ & \\
\hline $\mathrm{BSAP}>10 \mathrm{ng} / \mathrm{mL}$ & $84 \% / 70 \%$ & $90 \%$ & \\
\hline iPTH $>200 \mathrm{pg} / \mathrm{mL}$ & $72 \% / 80 \%$ & $92 \%$ & \\
\hline iPTH $>150 \mathrm{pg} / \mathrm{mL}$ & $78 \% / 70 \%$ & $89 \%$ & \\
\hline $\mathrm{BASP}+\mathrm{iPTH}>20 \mathrm{ng}>200 \mathrm{pg} / \mathrm{mL}$ & $100 \% / 80 \%$ & $94 \%$ & \\
\hline $\mathrm{iPTH}>300 \mathrm{pg} / \mathrm{mL}$ & $58 \% / 77.7 \%$ & & NFK-KDOQI guideline [24] \\
\hline iPTH $>9$ X ULN & $37 \% / 85.8 \%$ & & KDIGO guideline [24] \\
\hline Blood marker & $\begin{array}{l}\text { Low turnover sensitivity / specific- } \\
\text { ity }\end{array}$ & Positive predictability & Study \\
\hline $\mathrm{BSAP}<20 \mathrm{ng} / \mathrm{mL}$ & $100 \% / 100 \%$ & $100 \%$ & Ureña-Torres $\mathrm{P}$ et al. [21] \\
\hline $\mathrm{BSAP}<15 \mathrm{ng} / \mathrm{mL}$ & $83 \% / 97 \%$ & $83 \%$ & \\
\hline $\mathrm{BSAP}>10 \mathrm{ng} / \mathrm{mL}$ & $70 \% / 84 \%$ & $58 \%$ & \\
\hline iPTH $<200 \mathrm{pg} / \mathrm{mL}$ & $80 \% / 72 \%$ & $47 \%$ & \\
\hline iPTH $<150 \mathrm{pg} / \mathrm{mL}$ & $70 \% / 78 \%$ & $50 \%$ & \\
\hline $\mathrm{BASP}+\mathrm{iPTH}<20 \mathrm{ng}<200 \mathrm{pg} / \mathrm{mL}$ & $80 \% / 100 \%$ & $100 \%$ & \\
\hline $\mathrm{BSAP}<27 \mathrm{U} / \mathrm{IL}$ & $78.1 \% / 86.4 \%$ & $75 \%$ & Couttenye M. et al. [22] \\
\hline $\mathrm{iPTH}<150 \mathrm{pg} / \mathrm{mL}$ & $80.6 \% / 76.2 \%$ & $65 \%$ & \\
\hline $\mathrm{BSAP}<12.9 \mathrm{ng} / \mathrm{mL}$ & $100 \% / 94 \%$ & $72 \%$ & Coen, G. et al. [13] \\
\hline iPTH $<79.7 \mathrm{pg} / \mathrm{mL}$ & $88.9 \% / 90.6 \%$ & & \\
\hline iPTH $<150 \mathrm{pg} / \mathrm{mL}$ & $68.6 \% / 61.2 \%$ & & NFK-KDOQI guideline [24] \\
\hline iPTH $<2$ X ULN & $65 \% / 67.3 \%$ & & KDIGO guideline [24] \\
\hline
\end{tabular}

Table 2 Discrepancies between intact PTH (iPTH) and bone-specific alkaline phosphatase (BSAP)

\begin{tabular}{ll}
\hline Relatively $\uparrow$ iPTH / N- $\downarrow$ BSAP & Relatively $\uparrow$ BSAP / N- $\downarrow$ iPTH \\
\hline Different degrees of multifactorial skeletal resistance to PTH: & Extra-skeletal synthesis \\
Down-regulation of the PTH receptor & PTH-independent osteoblast activity: (interleukins 1/6/10; TNF) \\
Uremia & Cross-reactivity (16\% with total AP) \\
Phosphate & Phosphate-Calcium-Urea in the media \\
$\downarrow$ calcitriol & Aluminum overload (?) \\
Different PTH fragments (i.e. 7-84 PTH) & Osteomalacia (?) \\
Bone morphogenetic proteins (BMPs) & Paget's Disease \\
Others & Lytic bone diseases (metastasis,...) \\
\hline
\end{tabular}

Adapted from references [26, 27, 35, 62]

did not see any correlation between $\triangle \mathrm{iPTH}$ and $\triangle \mathrm{BSAP}$ over a 6-week interval [28].

Increased serum iPTH levels with low BSAP may reflect different degrees of the well-known multifactorial skeletal resistance or decreased calcemic response to PTH (also called hypo-responsiveness to PTH), clearly described in CKD [29, 30]. Evanson reported it for the first time in 1996, when he noted that the calcemic response to an infusion of parathyroid extract was significantly lower in hypocalcemic patients with CKD compared with normal subjects or patients with primary hyperparathyroidism [31]. Subsequently, other authors extended these observations in patients with early CKD [32-34], confirming that a greater concentration of circulating $\mathrm{PTH}$ is required to maintain normal serum $\mathrm{Ca}$ levels in affected patients. In experimental conditions, when a fixed amount of PTH is infused into an experimental animal (i.e., subcutaneously through an Alzet pump), the calcemic response to PTH is also markedly decreased in animals with kidney disease as compared with sham controls [26, 27, 30, 35] (Fig. 3).

Hyperphosphatemia, low calcitriol, increasing age, and uremia itself, among others, have been described as contributing factors to skeletal resistance to PTH in CKD [26, 30, 35-38]. Moreover, down-regulation of osteoblastic PTH 
Fig. 3 The effect of renal failure and dietary phosphorus on the calcemic response to PTH in rats. Serum calcium concentration after a constant PTH infusion (Alzet pump) is shown for each of the threee dietary groups (high, modetate and low phosphorus diet), and for the different levels of renal function (normal, moderate and advanced renal failure). During the PTH infusion all rats received a calcium-free, very low phosphorus diet $(0.16 \%)$. Adapted from reference [26, 27]
Normal Renal Function
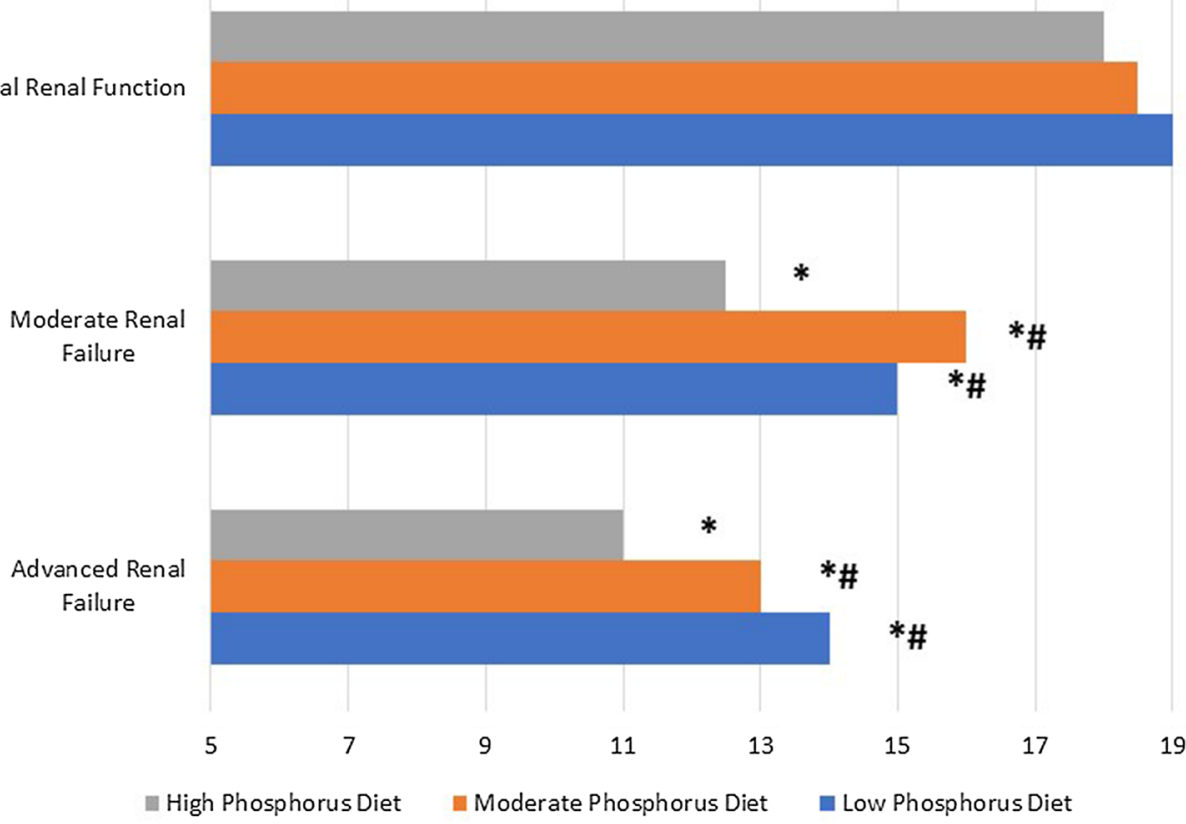

$P<0.05$ same diet, previous group

\# $\mathrm{P}<0.05$ vs high phosphorus diet receptors in CKD has also been associated with resistance to PTH in CKD [30, 39], similar to the decreased expression of several other related receptors in uremia (i.e., nuclear vitamin D receptor, transmembrane calcium-sensing receptor, FGFR/Klotho) [26, 29, 40-48]. Furthermore, resistance to the biological action of several hormones, such as resistance to insulin or growth hormone, is also a well-known feature of CKD [49, 50]. As a matter of fact, uremia may thus be considered a disease which extensively affects different types of receptors (uremia as a "receptor disease") and discrepancies between iPTH and BSAP are possible (Table 1). Additionally, iPTH is only indirectly associated with bone formation and represents much better the parathyroid activity than bone dynamics. This PTH hypo-responsiveness or resistance to PTH in CKD is also one of the reasons why a complete normalization of iPTH values in CKD patients should not be a treatment goal, due to this hypo-responsiveness and beyond the imprecision associated with the inappropriate detection of serum PTH fragments in CKD. Nevertheless, we do not know yet which is the adequate PTH goal associated with a normal bone formation rate or improved survival at every stage of CKD [51, 52]. In fact, we do not even know whether the target to optimize bone disease and survival end-points is equivalent. In any case, there is a generalized agreement on that low PTH levels (i.e., $<2 \mathrm{x}$ the upper limit of normality) are associated with adynamic bone disease (and its potential complications) in dialysis patients [51-53]. In this setting, the evaluation of
APs and/or BSAP may especially provide clinical useful information about the actual bone status.

Several circulating human BSAP isoforms have also recently been described [54]. They are distinguished by the variable amounts of sialic acid residues or glycosylation differences in the molecule $[55,56]$, contributing to distinct catalytic properties [56]. Three circulating human BSAP isoforms [B1, B2, and Bone/intestine (B/I)] can be distinguished in healthy individuals. $\mathrm{B} / \mathrm{I}$ and $\mathrm{B} 2$ isoforms are specially increased in CKD [57]. Moreover, a fourth isoform that only circulates in the serum of CKD patients stages 4 and 5 and not in normal subjects has been recently reported $[54,58,59]$. This BSAP isoform is named $\mathrm{B} 1 \mathrm{x}$ and it was found in 21 patients (53\%) who had lower median levels of BSAP, bone/intestine, B1, B2, and iPTH (49 versus $287 \mathrm{pg}$ / $\mathrm{mL})$, compared with patients without $\mathrm{B} 1 \mathrm{x}(\mathrm{P}<0.001)$. Thirteen patients $(65 \%)$ with low bone turnover and 8 patients $(40 \%)$ with non-low bone turnover $(\mathrm{P}<0.2)$ had detectable B1x. Interestingly, B1x was the only biochemical parameter that inversely correlated with histomorphometric parameters of osteoblastic number and activity, indicating bone turnover [54]. Receiver operating characteristic curves showed that $\mathrm{B} 1 \mathrm{x}$ could be used for the diagnosis of low bone turnover (area under the curve [AUC], 0.83), whereas BASP (AUC, 0.89) and iPTH (AUC, 0.85) were useful for the diagnosis of non-low-turnover-bone disease [54]. The conclusion of this study is that B1x, BSAP as well as iPTH have similar diagnostic accuracy in distinguishing low from non-low 
bone turnover; additionally, the presence of B1x was diagnostic of low bone turnover, whereas elevated BSAP and iPTH levels were useful for the diagnosis of non-low turnover bone disease. It is necessary to emphasize that this study was performed in a small number of participants and the original results need to be confirmed since the $\mathrm{B} 1 \mathrm{x}$ isoform utility has not been clearly clarified in clinical grounds. It is noteworthy that B1x needs high-performance liquid chromatography methods for its measurement [54]. Calcifying human aortic vascular smooth muscle cells express the four known BSAP isoforms and B/I, B1X, and B2 seem to play different biological functions during calcification [60].

Finally, increased BSAP and low iPTH levels are also a potential clinical situation (Table 2). Extra-skeletal synthesis of BSAP, the presence of P-Ca-Urea in the media, PTH-independent osteoblast activity (i.e., IL1-, IL6-, IL10-, TNF-mediated), cross-reactivity among different APs (16\% for total AP) may explain these observations. In fact, Jean et al. have shown that, in CKD-5D patients with chronic liver disease, serum BSAP levels are not a more useful biomarker of bone turnover than total AP owing to its cross-reactivity with total AP, even when the BASP/total AP ratio is used [61]. Lastly, the potential presence of aluminum overload, osteomalacia, Paget's disease, or lytic bone lesions could explain in some circumstances the discrepancies between BSAP and iPTH [62].

\section{Association of APs and Survival}

Total AP has been associated with inflammation (high serum C-reactive protein), hospitalization rates, and allcause/or cardiovascular mortality, even adjusted to hepatic function [63-67]. This association has been described in pre-dialysis CKD, hemodialysis (across all ages but especially in young patients), peritoneal dialysis, and transplant patients (pre-transplant values) [19, 68-76]. It has also been reported in diverse races such as AfricanAmerican or Japanese populations, and among survivors of myocardial infarction and in the general population [19, 70, 71, 77-79]. Total AP has also been associated with increased coronary artery calcification, incident peripheral arterial disease, vascular stiffening, and sudden cardiac death (APs, regardless of source, ultimately promote vascular calcification) $[80,81]$. Total AP has been associated with worsening bone mineral density, higher hip fracture events and worse responsiveness to erythropoiesis stimulating factors [79, 82-84]. Higher pre-dialysis serum AP levels were independently associated with higher dialysis mortality risk [76]. Compared with patients in the lowest AP quartile $(<66 \mathrm{U} / \mathrm{L})$, those in the highest quartile ( $\geq 111.1 \mathrm{U} / \mathrm{L}$ ) had multivariable-adjusted hazard/subhazard ratios (95\% confidence interval) of 1.42 (1.34-1.51), $1.43(1.09-1.88)$ and $1.39(1.09-1.78)$ for all-cause, cardiovascular and infection-related mortality, respectively [76]. On the other hand, hemodialysis patients with pre-transplant serum AP $>120 \mathrm{U} / \mathrm{L}$ had also unfavorable post-transplant mortality not observed by iPTH or serum Ca levels [70].

Importantly, an incremental and linear relationship between higher total AP (>120 U/L) and all-cause death hazard ratio was described first in hemodialysis patients [66, 85], as opposed to the U-shaped curve describing the relationship between iPTH and mortality (both high and low iPTH are associated with higher death risk) [66, 72, 85-88] (Fig. 4). These findings are described in "fully" adjusted models, using baseline, non-time dependent, time-averaged or time-varying analyses in different dialysis populations, including peritoneal dialysis and non-dialysis dependent CKD patients [66, 72, 86-88]. Consequently, it has been postulated that total AP may be better than iPTH as a marker of cardiovascular and bone disease [19, 89].

These incremental and linear association between higher serum total AP levels and higher mortality may additionally provide important clinical information for the management and achievement of beneficial clinical goals in these patients. Since total AP but not BSAP has been as frequently associated with inflammation and mortality in representative samples (i.e., the 1999-2004 National Health and Nutrition Examination Survey $(n=10,707)$ [65], it would seem that bone disease would unlikely account for these associations and the discrepancy between total AP and BSAP. Low number of deaths, low statistical power, and CKD with only minor decreases of glomerular filtration rate could have played a role, but intermittent or chronic neutrophil activation or the presence of subclinical hepatic disease have been suggested as potential causal mechanisms. In fact, BSAP was indeed a predictor of mortality in both CKD and dialysis patients in other studies $[74,90]$. Not surprisingly, no uniform or weaker associations with mortality, vascular calcification, bone mineral density or long-term hip fracture risk have also been reported for both APs [84, 91, 92].

Of note, the direct association of AP levels with mortality persists in different iPTH strata, even including iPTH $<150 \mathrm{pg} / \mathrm{ml}(<2 \mathrm{X}$ ULN) $[66,85]$. Thus, low APs have been associated with greater survival, questioning the widely accepted concept that low-turnover-bone disease (i.e., adynamic bone disease) increases mortality. Nevertheless, some time-averaged measurements did not show lower risk of death in the lowest AP categories (maybe because fractures, vascular calcification, or associated hypercalcemia mitigate the potential benefits). For instance, a study including 407 unselected European CKD-5D subjects showed a statistically significant association between total AP with crude mortality and also a stronger death risk association of total AP and individual lowest skeletal BSAP with crude mortality [93]. Finally, associations of change of total AP 
Fig. 4 Different relationship (U-shape vs linear) between serum total alkaline phosphatase and intact PTH quartiles and all-cause death hazard ratio

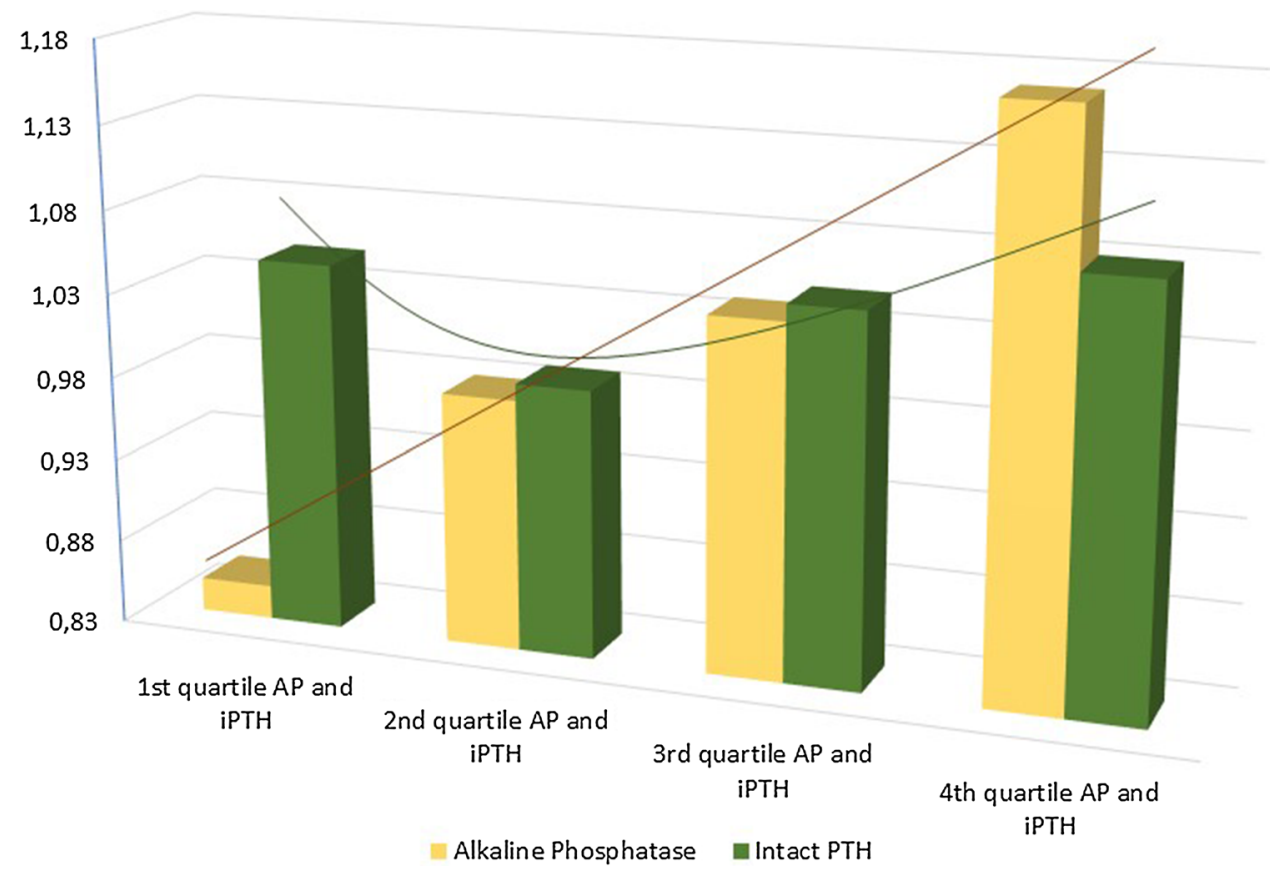

Frequent associations between AP or BSAP levels and and all-cause 6-month mortality have also recently been described in a huge cohort of 102,754 incident hemodialysis patients [94].

\section{APs and Vascular Calcification}

It is well known that the process of vascular calcification involves chondro-osteoblastic conversion of vascular smooth muscle cells (VSMCs), evidenced by the loss of VSMC markers (such as $\alpha$-actin) and the novo expression of osteoblast markers (TNAP, osteocalcin, osteopontin) or osteocyte markers such as sclerostin and podoplanin [95-99]. All BSAP isoforms, including B1x, are also expressed in vascular smooth muscle cells (Fig. 2), the calcification of which is associated with a strong increase in BSAP activity level $[60,100]$. Experimental studies also illustrate the key role played by TNAP in the process of arterial mineralization. A mouse model overexpressing human TNAP in VSMCs and in endothelial cells shows extensive vascular calcification, hypertension, and shortened lifespan [101, 102]. Treatment of these animals with a TNAP inhibitor (SBI-425) significantly reduced vascular calcifications and improved survival [101]. Interestingly, in patients with hyperphosphatasia, a group of disorders that feature elevated serum TNAP activity (i.e., Paget's disease of bone), there is no clear evidence for an association with vascular calcification [103]. This may indicate that only membrane-bound TNAP plays a role in vascular calcification, or that other vascular-specific cofactors are necessary to induce vascular calcification in the context of elevated TNAP [103]. One such component was postulated to be collagen I expression by osteoblasts [103-105]. vascular calcification have been reported not only in CKD but also in osteoporotic patients [106,107]. Consequently, as it will be emphasized later, it has been suggested that not only pyrophosphate or phytate (another endogenous crystallization inhibitor) but also inhibitors of alkaline phosphatase could potentially prevent, attenuate or reverse the progression of VSMC calcification [2, 108-117]. However, it is important to note that these strategies may interfere with normal bone formation. Therefore, APs may have both friends and foes action on bone and mineral homeostasis since, at one point, APs provide phosphate in order to improve bone mineralization but APs may induce vascular calcification and consequently increase cardiovascular morbidity and mortality, especially in CKD and hyperphosphatemic patients. Independent actions on vessels and bone have been described $[101,110]$.

Another possible link between total AP or BSAP and mortality comes from the recognition that TNAP stimulates hydrolysis of pyrophosphate, and thus high levels of circulating TNAP or TNAP locally produced by calcifying VSMCs could lower pyrophosphate concentrations, thus favoring vascular calcification [2] (Fig. 2). APs are also speculated to inactivate the calcification inhibitor osteopontin through dephosphorylation [19, 118]. On the other hand, matrix Gla protein (MGP) - a well-known inhibitor of vascular mineralization-may indirectly reduce AP activity by inhibiting bone morphometric protein-2 induction of AP [119, 120]. It has also recently been described that FGF23 is a suppressor of TNAP gene expression via a klotho-independent, FGF receptor- (FGFR3)-mediated signaling axis in osteoblasts, 
leading to inhibition of mineralization through accumulation of the TNAP substrate pyrophosphate and decreased local inorganic free P [121, 122]. Due to the increased activity of TNAP and elevated levels of inorganic $\mathrm{P}$ in the failing heart compared with the normal heart, upstream regulators of TNAP such as secreted Frizzle-related protein 2 (sFRP2) have been associated with cardiac fibro-calcification [123]. Furthermore, TNAP seems to favor intracellular deposition of lipids in pre-adipocytes (124), a mechanism that in VSMCs could be additive for calcifications [125], and BASP or intestinal AP levels also correlate with parameters of glucose metabolism and of metabolic syndrome, further increasing links with vascular calcification and survival [126-128]. Finally, higher APs levels are also associated with lower calcidiol levels [129, 130], which are in turn associated with increased mortality per se [131]. A recent review on the mechanisms associating AP activity, vascular calcification, inflammation, endothelial dysfunction, cardiovascular disease, and survival has been recently published [19].

\section{Pharmacology and Genetics}

In addition to classical treatments which affect bone formation rate and thus indirectly decrease AP's levels (i.e., vitamin D derivatives and calcimimetics) [132-135], several manoeuvers are currently underway attempting either to directly or indirectly influence pyrophosphate deficiency or regulate the activity of TNAP's. Whereas plasma pyrophosphate is reduced in hemodialysis patients and it is cleared by dialysis [136], AP is neither dialyzable nor filterable by the normal kidney, although it is possible that with convective and very high-flux hemodialysis or hemofiltration plasma AP levels could slightly decrease [137]. Thus, TNAP evolved as a druggable target for the treatment and/or prevention of VSMC calcification [2, 112]. As such, phytate in the form of the hexasodium salt SNF472 is currently being developed for the treatment of calciphylaxis and cardiovascular calcification in hemodialysis patients [138-140]. The activity of several related transporters and enzymes discovered from genetic diseases associated with severe vascular calcification are also currently under scrutiny. Thus, ABCC6 is an efflux transporter primarily expressed in liver which facilitates the release of adenosine triphosphate (ATP) from hepatocytes. Within the liver vasculature, ATP is converted into pyrophosphate and thus liver ABCC6-mediated ATP secretion seems to be the main source of pyrophosphate in the systemic circulation [141]. The chemical chaperone 4-phenylbutyrate (4-PBA) seems a promising strategy for allele-specific therapy of ABCC6-associated calcification disorders [142]. ENPP1 -Fc fusion proteins seem to prevent mortality and vascular calcifications in a rodent model of generalized arterial calcification of infancy (GACI) [143].
ANK is also a nonenzymatic plasma-membrane pyrophosphate channel that supports pyrophosphate levels (Fig. 1) [144-146]. Of note, pyrophosphate treatment also ameliorates a mouse model of Hutchinson-Gilford progeria syndrome, in which excessive vascular calcification is caused by reduced extracellular accumulation of pyrophosphate that results from increased TNAP activity and diminished ATP availability caused my mitochondrial dysfunction in VSMC [147]. Interestingly, in the field of nephrology, peritoneal delivery of sodium pyrophosphate blocks the progression of pre-existing vascular calcification in an experimental model in mice [148]. On the other hand, benzofuran derivatives and other compounds such as SBI-425 mentioned earlier seem to selectively inhibit TNAP [101, 112-115, 149]. This latter compound seems to inhibit vascular calcification without a negative effect on bone mineralization [101]. Apabetalone (RVX-208), a BET (bromodomain and extraterminal)motif inhibitor, modulates the epigenetic regulation of several genes [150], repressing new pathways that contribute to cardiovascular disease [151]. Interestingly, apabetalone reduces circulating levels of APs, which was associated with a marked reduction of major cardiovascular events [152, 153]. A large phase III study of this compound for the prevention of cardiovascular complications in type II diabetes is ongoing [154].

\section{AP Targeting in Other Clinical Conditions}

Systemic administration of APs (bovine intestinal AP, human placental AP, recombinant or soluble non-targeted chimeric APs) can exert nephroprotective and anti-inflammatory effects in sepsis and after cardiac surgery $[19,155$, 156]. Dephosphorylation and thereby detoxification of detrimental molecules involved in the pathogenesis of sepsisassociated AKI [i.e., endotoxins like di-phosphoryl lipopolysaccharide from the cell wall of Gram-negative bacteria or nucleotides like ATP, a pro-inflammatory mediator released during cellular stress, which can be converted by AP (ATPase activity) into the tissue-protective and anti-inflammatory molecule adenosine] seem to be responsible for this protective effect $[157,158]$. Further clinical studies are needed to elucidate whether intestinal APs could prevent and combat systemic and intestinal inflammation or dysbiosis, and/or metabolic syndrome [19]. Traditional herbal remedies like curcumin, which increases the expression of intestinal APs, have been shown to correct gut permeability in CKD [159] and inhibit manifestations of metabolic syndrome [160].

On the other hand, hypophosphatasia (HPP) is a rare hereditary metabolic disorder caused by inactivating mutations in ALPL [161]. Although these patients often have hyperphosphatemia and hypercalcemia, this disease is not associated with accelerated vascular calcification [19, 161]. Enzyme replacement therapy with asfotase- $\alpha$, a recombinant 
mineral-targeted human TNAP, has resulted in dramatic improvements in bone mineralization and survival [19]. However, long-term administration or managing HPP in adults, especially in the presence of hyperphosphatemia, could theoretically promote vascular calcification and cardiovascular complications $[19,161]$.

\section{Conclusion}

Considering that the biological variation of BSAP is less than half that reported for iPTH, the APs assays have been judged to be more reliable for diagnostic (bone disease) and prognostic (clinical outcomes) purposes [162]. Thus, the use of APs as an alternative marker or target goal for bone mineral metabolism and cardiovascular disease in the setting of CKD-MBD has been underlined [9, 19, 163]. However, costs, availability, former clinical experience, and the lack of studies or clear-cut targets using APs as a primary therapeutic goal for significant outcomes still represent significant strengths for the iPTH assay [164], and consequently guidelines still recommend frequent measurement of iPTH in order to determine PTH trends to implement the appropriate therapy. The additional information provided by APs, with a much lower intraindividual coefficient of variation, should also be taken into account $[162,165]$. Despite we lack prospective data demonstrating that lowering APs would alter fracture or mortality outcomes, the diagnostic potential of APs in the management of renal osteodystrophy should not be forgotten, notwithstanding the major gap for these recommendations in current guidelines [8]. Moreover, the additional information provided by APs on survival should be definitely underlined in clinical grounds, whereas their narrow relationship with vascular calcification, cardiovascular disease, and mortality results in further investigation for the development of novel therapeutic approaches, not only for CKD but also for sepsis, AKI, metabolic syndrome, diabetes, or aging.

Acknowledgements Dr Jordi Bover belongs to the Spanish National Network of Kidney Research RedinRen (RD06/0016/0001 and RD12/0021/0033) and the Spanish National Biobank network RD09/0076/00064. Dr Jordi Bover also belongs to the Catalan Nephrology Research Group AGAUR 2009 SGR-1116 and collaborates with the Spanish Fundación Iñigo Alvarez de Toledo (FRIAT). We thank Mr. Ricardo Pellejero for his invaluable bibliographic assistance.

\section{References}

1. Mazzaferro S, Tartaglione L, Rotondi S, Bover J, Goldsmith D, Pasquali M (2014) News on biomarkers in CKD-MBD. Semin Nephrol 34(6):598-611

2. Lomashvili K, Garg P, Narisawa S, Millan JL, O'neill WC (2008) Upregulation of alkaline phosphatase and pyrophosphate hydrolysis: potential mechanism for uremic vascular calcification. Kidney Int 73(9):1024-1030

3. Schoppet M, Shanahan CM (2008) Role for alkaline phosphatase as an inducer of vascular calcification in renal failure? Kidney Int 73(9):989-991

4. Schibler D, Russell RGG, Fleisch H (1968) Inhibition by pyrophosphate and poly-phosphate of aortic calcification induced by vitamin D3 in rats. Clin Sci 35:363-372

5. London GM (2012) Bone-vascular cross-talk. J Nephrol 25(5):619-625

6. Bover J, Ureña-Torres P, Lloret MJ, Ruiz-García C, DaSilva I, Diaz-Encarnacion M, Mercado C, Mateu S, Fernandez E, Ballarin J (2016) Integral pharmacological management of bone mineral disorders in chronic kidney disease (part I): from treatment of phosphate imbalance to control of PTH and prevention of progression of cardiovascular calcification. Expert Opin Pharmacother 17(9):1247-1258

7. Bover J, Ureña-Torres P, Lloret MJ, Ruiz C, DaSilva I, DiazEncarnacion MM, Mercado C, Mateu S, Fernández E, Ballarin J (2016) Integral pharmacological management of bone mineral disorders in chronic kidney disease (part II): from treatment of phosphate imbalance to control of PTH and prevention of progression of cardiovascular calcification. Expert Opin Pharmacother 17(10):1363-1373

8. Shantouf R, Kovesdy CP, Kim Y, Ahmadi N, Luna A, Luna C, Rambod M, Nissenson AR, Budoff MJ, Kalantar-Zadeh K (2009) Association of serum alkaline phosphatase with coronary artery calcification in maintenance hemodialysis patients. Clin J Am Soc Nephrol 4(6):1106-1114

9. Lau W, Kalantar-Zadeh K (2014) Towards the revival of alkaline phosphatase for the management of bone disease, mortality and hip fractures. Nephrol Dial Transplant 29:1450-1452

10. Harris H (1990) The human alkaline phosphatases: what we know and what we don't know. Clin Chim Acta 186(2):133-150

11. Linder C, Narisawa S, Millán L, Magnusson P (2009) Glycosylation differences contribute to distinct catalytic properties among bone alkaline phosphatase isoforms. Bone 45(5):987-993

12. Bervoets R, Spasovski B, Behets J, Dams G, Polenakovic H, Zafirovska K, D'Haese, C (2003) Useful biochemical markers for diagnosing renal osteodystrophy in predialysis end-stage renal failure patients. Am J Kidney Dis 41(5):997-1007

13. Coen G, Ballanti P, Bonucci E, Calabria S, Centorrino M, Fassino V, Sardella D (1998) Bone markers in the diagnosis of low turnover osteodystrophy in haemodialysis patients. Nephrol Dial Transplant 13(9):2294-2302

14. Ortega O, Rodriguez I, Hinostroza J, Laso N, Callejas R, Gallar P, Vigil A (2011) Serum alkaline phosphatase levels and left ventricular diastolic dysfunction in patients with advanced chronic kidney disease. Nephron Extra 1(1):283-291

15. Walker AW (1974) Increased intestinal alkaline phosphatase in serum of patients on maintenance haemodialysis. Lancet 303(7862):866-867

16. De Broe E, Van Hoof O (1991) Multiple forms of alkaline phosphatase in plasma of hemodialysis patients. Clin Chem 37(6):783-784

17. Tibi L, Chabra C, Sweeting M, Winney J, Smith F (1991) Multiple forms of alkaline phosphatase in plasma of hemodialysis patients. Clin Chem 37(6):815-820

18. Zetterberg H (2005) Increased serum concentrations of intestinal alkaline phosphatase in peritoneal dialysis. Clin Chem 51(3):675-676

19. Haarhaus M, Brandenburg V, Kalantar-Zadeh K, Stenvinkel P, Magnusson P (2017) Alkaline phosphatase: a novel treatment target for cardiovascular disease in CKD. Nature Rev Nephrol 13(7):429-442 
20. Ureña Torres P, de Vernejoul C (1999) Circulating biochemical markers of bone remodeling in uremic patients. Kidney Int 55(6):2141-2156

21. Ureña Torres P, Hruby M, Ferreira A, Ang KS, de Vernejoul MC (1996) Plasma total versus bone alkaline phosphatase as markers of bone turnover in hemodialysis patients. J Am Soc Nephrol 7(3):506-512

22. Couttenye M, D'Haese C, Van Hoof O, Lemoniatou E, Goodman W, Verpooten A, De Broe E (1996) Low serum levels of alkaline phosphatase of bone origin: a good marker of adynamic bone disease in haemodialysis patients. Nephrol Dial Transplant 11(6):1065-1072

23. Behets J, Spasovski G, Sterling R, Goodman G, Spiegel M, De Broe E, D'haese PC (2015) Bone histomorphometry before and after long-term treatment with cinacalcet in dialysis patients with secondary hyperparathyroidism. Kidney Int 87(4):846-856

24. Sprague SM, Bellorin-Font E, Jorgetti V, Carvalho AB, Malluche HH, Ferreira A, Rojas E (2016) Diagnostic accuracy of bone turnover markers and bone histology in patients with CKD treated by dialysis. Am J Kidney Dis 67(4):559-566

25. Ueda M, Inaba M, Okuno S, Maeno Y, Ishimura E, Yamakawa T, Nishizawa Y (2005) Serum BAP as the clinically useful marker for predicting BMD reduction in diabetic hemodialysis patients with low PTH. Life Sci 77(10):1130-1139

26. Bover J, Jara A, Trinidad P, Rodriguez M, Martin-Malo A, Felsenfeld AJ (1994) The calcemic response to PTH in the rat: effect of elevated PTH levels and uremia. Kidney Int 46(2):310-317

27. Bover J, Jara A, Trinidad P, Rodriguez M, Felsenfeld A (1999) Dynamics of skeletal resistance to parathyroid hormone in the rat: effect of renal failure and dietary phosphorus. Bone 25(3): $279-85$

28. Delanaye P, Dubois E, Jouret F, Krzesinski M, Moranne O, Cavalier E (2013) Parathormone and bone-specific alkaline phosphatase for the follow-up of bone turnover in hemodialysis patients: is it so simple? Clin Chim Acta 417:35-38

29. Llach F, Bover J (2000). Renal Osteodystrophies. Brenner BM, editor. Brenner and Rector's "The Kidney". 6th edn. Filadelfia. W.B. Saunders Company. pp 2103-2186

30. Evenepoel P, Bover J, Ureña Torres P (2016) Parathyroid hormone metabolism and signaling in health and chronic kidney disease. Kidney Int 90(6):1184-1190

31. Evanson JM (1966) The response to the infusion of parathyroid extract in hypocalcaemic states. Clin Sci 31(1):63-75

32. Massry S, Stein R, Garty J, Arieff A, Coburn J, Norman A, Friedler R (1976) Skeletal resistance to the calcemic action of parathyroid hormone in uremia: role of 1,25 $(\mathrm{OH}) 2$ D3. Kidney Int 9(6):467-474

33. Llach F, Massry S, Singer F, Kurokawa K, Kaye J, Coburn J (1975, August) Skeletal resistance to endogenous parathyroid hormone in patients with early renal failure. A possible cause for secondary hyperparathyroidism. J Clin Endocrinol Metab 41(2):339-345

34. Wilson L, Felsenfeld A, Drezner MK, Llach F (1985). Altered divalent ion metabolism in early renal failure: role of 1,25(OH)2D. Kidney Int 27(3):565-573

35. Bover J, Rodriguez M, Trinidad P, Jara A, Martinez ME, Machado L, Llach F, Felsenfeld AJ (1994) Factors in the development of secondary hyperparathyroidism during graded renal failure in the rat. Kidney Int 1994;45(4):953 - 61

36. Andress L, Howard A, Birnbaum S (1991) Identification of a low molecular weight inhibitor of osteoblast mitogenesis in uremic plasma. Kidney Int 39(5):942-945

37. Mathew S, Davies M, Lund R, Saab G, Hruska A (2006) Function and effect of bone morphogenetic protein-7 in kidney bone and the bone-vascular links in chronic kidney disease. Eur J Clin Invest 36(s2):43-50

38. Portale A, Lonergan E, Tanney D, Halloran B (1997) Aging alters calcium regulation of serum concentration of parathyroid hormone in healthy men. Am J Physiol 272(1 Pt 1):E139-146

39. Ureña P, Kubrusly M, Mannstadt M, Hruby M, Trinh MM, Silve C, Lacour B, Abou-Samra AB, Segre GV, Drüeke T (1994) The renal PTH/PTHrP receptor is down-regulated in rats with chronic renal failure. Kidney Int 45(2):605 - 11

40. Galitzer H, Ben-Dov Z, Silver J, Naveh-Many T (2010) Parathyroid cell resistance to fibroblast growth factor 23 in secondary hyperparathyroidism of chronic kidney disease. Kidney Int 77(3):211-218

41. Komaba H, Goto S, Fujii H, Hamada Y, Kobayashi A, Shibuya K, Tominaga Y, Otsuki N, Nibu K, Nakagawa K, Tsugawa N, Okano T, Kitazawa R, Fukagawa M, Kita T (2010) Depressed expression of Klotho and FGF receptor 1 in hyperplastic parathyroid glands from uremic patients. Kidney Int 77(3):232-238

42. Brown A, Ritter C, Finch J, Slatopolsky E (1999) Decreased calcium-sensing receptor expression in hyperplastic parathyroid glands of uremic rats: role of dietary phosphate. Kidney Int 55(4):1284-1292

43. Brown A, Dusso A, Lopez-Hilker S, Lewis-Finch J, Grooms P, Slatopolsky E (1989) 1,25-(OH)2D receptors are decreased in parathyroid glands from chronically uremic dogs. Kidney Int 35(1):19-23

44. Mithal A, Kifor O, Kifor I, Vassilev P, Butters R, Krapcho K, Simin R, Fuller F, Hebert S, Brown E (1995) The reduced responsiveness of cultured bovine parathyroid cells to extracellular $\mathrm{Ca} 2+$ is associated with marked reduction in the expression of extracellular $\mathrm{Ca}(2+)$-sensing receptor messenger ribonucleic acid and protein. Endocrinology 136(7):3087-3092

45. Ritter C, Finch J, Slatopolsky E, Brown A (2001, November) Parathyroid hyperplasia in uremic rats precedes down-regulation of the calcium receptor. Kidney Int 60(5):1737-1744

46. Fukuda N, Tanaka H, Tominaga Y, Fukagawa M, Kurokawa K, Seino Y (1993) Decreased 1,25-dihydroxyvitamin D3 receptor density is associated with a more severe form of parathyroid hyperplasia in chronic uremic patients. J Clin Invest 92(3):1436-1443

47. Silver J, Kilav R, Naveh-Many T (2002) Mechanisms of secondary hyperparathyroidism. Am J Physiol Renal Physiol 283(3):367-376

48. Román-García P, Carrillo-López N, Naves-Díaz M, Rodríguez I, Ortiz A, Cannata-Andía B (2012) Dual-specificity phosphatases are implicated in severe hyperplasia and lack of response to FGF23 of uremic parathyroid glands from rats. Endocrinology 153(4):1627-1637

49. DeFronzo RA, Alvestrand A, Smith D, Hendler R (1981) Insulin resistance in uremia. J Clin Invest 67:563-568

50. Blum WF, Ranke MB, Kietzmann K, Tonshoff B, Mehls (1991) Growth hormone resistance and inhibition of somatomedin activity by excess of insulin-like growth factor binding protein in uraemia. Pediatr Nephrol 5 0:539-544

51. Ketteler M, Block GA, Evenepoel P, Fukagawa M, Herzog CA, McCann L, Moe SM, Shroff R, Tonelli MA, Toussaint ND, Vervloet MG, Leonard MB (2017) Executive summary of the 2017 KDIGO chronic kidney disease-mineral and bone disorder (CKD-MBD) guideline update: what's changed and why it matters. Kidney Int 92(1):26-36

52. Ketteler M, Elder G, Evenepoel P, Ix J, Jamal S, Lafage-Proust M, Shroff R, Thadhani R, Tonelli M, Kasiske B, Wheeler D, Leonard M (2015) Revisiting KDIGO clinical practice guideline on chronic kidney disease-mineral and bone disorder: a commentary from a kidney disease: improving global outcomes controversies conference. Kidney Int 87(3):502-528 
53. Bover J, Ureña Torres P, Brandenburg V, Goldsmith D, Ruiz C, DaSilva I, Bosch RJ (2014) Adynamic bone disease: from bone to vessels in chronic kidney disease. Semin Nephrol 34(6):626-640

54. Haarhaus M, Monier-Faugere M, Magnusson P, Malluche $\mathrm{H}$ (2015) Bone alkaline phosphatase isoforms in hemodialysis patients with low versus non-low bone turnover: a diagnostic test study. Am J Kidney Dis 66(1):99-105

55. Magnusson P, Farley R (2002) Differences in sialic acid residues among bone alkaline phosphatase isoforms: a physical, biochemical, and immunological characterization. Calcif Tissue Int 71(6):508-518

56. Halling Linder C, Narisawa S, Millán J, Magnusson P (2009) Glycosylation differences contribute to distinct catalytic properties among bone alkaline phosphatase isoforms. Bone 45(5):987-993

57. Magnusson P, Sharp A, Magnusson M, Risteli J, Davie W, Larsson L (2001) Effect of chronic renal failure on bone turnover and bone alkaline phosphatase isoforms. Kidney Int 60(1):257-265

58. Swolin-Eide D, Hansson S, Larsson L, Magnusson P (2006) The novel bone alkaline phosphatase $\mathrm{B} 1 \mathrm{x}$ isoform in children with kidney disease. Pediatr Nephrol 21(11):1723-1729

59. Haarhaus M, Fernström A, Magnusson M, Magnusson P (2009) Clinical significance of bone alkaline phosphatase isoforms, including the novel $\mathrm{B} 1 \mathrm{x}$ isoform, in mild to moderate chronic kidney disease. Nephrol Dial Transplant 24(11):3382-3389

60. Haarhaus M, Arnqvist H, Magnusson P (2013) Calcifying human aortic smooth muscle cells express different bone alkaline phosphatase isoforms, including the novel B1x isoform. J Vasc Res 50(2):167-174

61. Jean G, Souberbielle J, Zaoui E, Lorriaux C, Mayor B, Hurot J, Deleaval P, Chazot C (2012) Total and bone-specific alkaline phosphatases in haemodialysis patients with chronic liver disease. Clin Biochem 45(6):436-439

62. Ureña-Torres P, De Vernejoul M (1999) Circulating biochemical markers of bone remodeling in uremic patients. Kidney Int 55(6):2141-2156

63. Damera S, Raphael L, Baird C, Cheung K, Greene T, Beddhu S (2011) Serum alkaline phosphatase levels associate with elevated serum C-reactive protein in chronic kidney disease. Kidney Int 79(2):228-233

64. Kunutsor K, Bakker J, Kootstra-Ros E, Gansevoort T, Gregson J, Dullaart P (2015) Serum alkaline phosphatase and risk of incident cardiovascular disease: interrelationship with high sensitivity C-reactive protein. PLoS ONE 10(7):1-16

65. Filipowicz R, Greene T, Wei G, Cheung A, Raphael K, Baird B, Beddhu S (2013) Associations of Serum Skeletal Alkaline Phosphatase with Elevated C-Reactive Protein and Mortality. Clin J Am Soc Nephrol 8:26-32

66. Kalantar-Zadeh K, Kuwae N, Regidor D, Kovesdy C, Kilpatrick R, Shinaberger C, McAllister C, Budoff M, Salusky I, Kopple J (2006) Survival predictability of time-varying indicators of bone disease in maintenance hemodialysis patients. Kidney Int 70:771-780

67. Blayney M, Pisoni P, Bragg-Gresham J, Bommer J, Piera L, Saito A, Akiba T, Keen M, Young E, Port F (2008) High alkaline phosphatase levels in hemodialysis patients are associated with higher risk of hospitalization and death. Kidney Int 74:655-663

68. Kovesdy C, Ureche V, Lu J, Kalantar-Zadeh K (2010) Outcome predictability of serum alkaline phosphatase in men with predialysis CKD. Nephrol Dial Transplant 25:3003-3011

69. Taliercio J, Schold J, Simon J, Arrigain S, Tang A, Saab S, Nally J, Navaneethan S (2013) Prognostic importance of serum alkaline phosphatase in CKD stages 3-4 in a clinical population. Am J Kidney Dis 62(4):703-710
70. Molnar M, Kovesdy C, Mucsi I, Salusky I, Kalantar-Zadeh K (2012) Association of pre-kidney transplant markers of mineral and bone disorder with post-transplant outcomes. Clin J Am Soc Nephrol 7:1859-1871

71. Beddhu S, Ma X, Baird B, Cheung A, Greene T (2009) Serum alkaline phosphatase and mortality in African Americans with chronic kidney disease. Clin J Am Soc Nephrol 4:1805-1810

72. Rhee C, Molnar M, Lau W, Ravel V, Kovesdy C, Mehrotra R, Kalantar-Zadeh K (2014) Comparative mortality-predictability using alkaline phosphatase and parathyroid hormone in patients on peritoneal dialysis and hemodialysis. Perit Dial Int 34:732-748

73. Lertdumrongluk P, Lau W, Park J, Rhee C, Kovesdy C, KalantarZadeh K (2013) Impact of age on survival predictability of bone turnover markers in hemodialysis patients. Nephrol Dial Transplant 28:2535-2545

74. Kobayashi I, Shidara K, Okuno S, Yamada S, Imanishi Y, Mori K, Ishimura E, Shoji S, Yamakawa T, Inaba M (2012) Higher serum bone alkaline phosphatase as a predictor of mortality in male hemodialysis patients. Life Sci 90(5-6):212-218

75. Chang J, Feng Y, Peng Y, Hsu S, Pai M, Chen H, Wu H, Yang J (2014) Combined alkaline phosphatase and phosphorus levels as a predictor of mortality in maintenance hemodialysis patients. Medicine (Baltimore) 93(18):1-8

76. Sumida K, Molnar M, Potukuchi P, Thomas F, Lu J, Obi Y, Rhee C, Streja E, Yamagata K, Kalantar-Zadeh K, Kovesdy C (2017) Prognostic significance of pre-end-stage renal disease serum alkaline phosphatase for post-end-stage renal disease mortality in late-stage chronic kidney disease patients transitioning to dialysis. Nephrol Dial Transplant. https://doi.org/10.1093/ndt/ gfw412 [E-pub ahead of print]

77. Tonelli M, Curhan G, Pfeffer M, Sacks F, Thadhani R, Melamed M, Wiebe N, Muntner P (2009) Relation between alkaline phosphatase, serum phosphate, and all-cause or cardiovascular mortality. Circulation 120(18):1784-1792

78. Drechsler C, Verduijn M, Pilz S, Krediet R, Dekker F, Wanner C, Ketteler M, Boeschoten E, Brandenburg V, NECOSAD Study Group (2011). Bone alkaline phosphatase and mortality in dialysis patients. Clin J Am Sc Nephrol 6 (7): 1752-1759

79. Maruyama Y, Taniguchi M, Kazama J, Yokoyama K, Hosoya T, Yokoo T, Shigematsu T, Iseki K, Tsubakihara Y (2014) A higher serum alkaline phosphatase is associated with the incidence of hip fracture and mortality among patients receiving hemodialysis in Japan. Nephrol Dial Transplant 29(8):1532-1538

80. Shantouf R, Kovesdy C, Kim Y, Ahmadi N, Luna A, Luna C, Rambod M, Nissenson A, Budoff M, Kalantar-Zadeh K (2009) Association of serum alkaline phosphatase with coronary artery calcification in maintenance hemodialysis patients. Clin J Am Soc Nephrol 4(6): 1106-1114

81. Chen J, Mohler E, Xie D, Shlipak M, Townsend R, Appel L, Ojo A, Schreiber M, Nessel L, Zhang X, Raj D, Strauss L, Lora C, Rahman M, Hamm L, He J, CRIC Study Investigators. (2016). Traditional and non-traditional risk factors for incident peripheral arterial disease among patients with chronic kidney disease. Nephrol Dial Transplant 31 (7): 1145-1151

82. Park J, Kovesdy C, Duong U, Streja E, Rambod M, Nissenson A, Sprague S, Kalantar-Zadeh K (2010) Association of serum alkaline phosphatase and bone mineral density in maintenance hemodialysis patients. Hemodial Int 14(2):182-192

83. Kalantar-Zadeh K, Lee G, Miller J, Streja E, Jing J, Robertson J, Kovesdy C (2009) Predictors of hyporesponsiveness to erythropoiesis-stimulating agents in hemodialysis patients. Am J Kidney Dis 53(5):823-834

84. Bergman A, Qureshi A, Haarhaus M, Lindholm B, Barany P, Heimburger O, Stenvinkel P, Anderstam B (2016) Total and bone-specific alkaline phosphatase are associated with bone 
mineral density over time in end-stage renal disease patients starting dialysis. J Nephrol 1:1-8

85. Regidor D, Kovesdy C, Mehrotra R, Rambod M, Jing J, McAllister C, Van Wyck D, Kopple J, Kalantar-Zadeh K (2008) Serum alkaline phosphatase predicts mortality among maintenance hemodialysis patients. J Am Soc Nephrol 19(11):2193 $-203$

86. Floege J, Kim J, Ireland E, Chazot C, Drueke T, de Francisco A, Kronenberg F, Marcelli D, Passlick-Deetjen J, Schernthaner G, Fouqueray B, Wheeler D, ARO Investigators (2011). Serum iPTH, calcium and phosphate, and the risk of mortality in a European haemodialysis population. Nephrol Dial Transplant 26(6): 1948-1955

87. Naves M, Passlick J, Guinsburg A, Marelli C, Fernández J, Rodríguez D, Cannata J (2011) Calcium, phosphorus, PTH and death rates in a large sample of dialysis patients from Latin America. The CORES Study. Nephrol Dial Transplant 26(6):1938-1947

88. Fernández-Martín JL, Martínez-Camblor P, Dionisi MP, Floege J, Ketteler M, London G, Locatelli F, Gorriz JL, Rutkowski B, Ferreira A, Bos WJ, Covic A, Rodríguez-García M, Sánchez JE, Rodríguez-Puyol D, Cannata-Andia JB; COSMOS group (2015). Improvement of mineral and bone metabolism markers is associated with better survival in haemodialysis patients: the COSMOS study. Nephrol Dial Transplant 30(9):1542-1551

89. Lau W, Kalantar-Zadeh K, Kovesdy C, Mehrotra R (2014) Alkaline phosphatase: better than PTH as a marker of cardiovascular and bone disease? Hemodial Int 18(4):720-724

90. Fahrleitner-Pammer A, Herberth J, Browning S, ObermayerPietsch B, Wirnsberger G, Holzer H, Dobnig H, Malluche H (2008) Bone markers predict cardiovascular events in chronic kidney disease. J Bone Miner Res 23(11):1850-1858

91. Robinson-Cohen C, Katz R, Hoofnagle A, Cauley J, Furberg C, Robbins J, Chen Z, Siscovick D, de Boer I, Kestenbaum B (2011) Mineral metabolism markers and the long-term risk of hip fracture: the cardiovascular health study. J Clin Endocrinol Metab 96(7):2186-2193

92. David C, Bover J, Voiculet C, Peride I, Petcu L, Niculae A, Covic A, Checherita I (2016) Coronary risk score for mineral bone disease in chronic non-diabetic hemodialysis patients: results from a prospective pilot study. Int Urol Nephrol 18:1-12

93. Beige J, Wendt R, Girndt M, Queck K, Fiedler R, Jehle P (2014) Association of serum alkaline phosphatase with mortality in non-selected European patients with CKD5D: an observational, three-centre survival analysis. BMJ Open 4(2):1-7

94. Soohoo M, Feng M, Obi Y, Streja E, Rhee C, Lau W, Wang J, Ravel V, Brunelli S, Kovesdy C, Kalantar-Zadeh K (2016) Changes in Markers of Mineral and Bone Disorders and Mortality in Incident Hemodialysis Patients. Am J Nephrol 43(2):85-96

95. Qiao J, Mertens R, Fishbein M, Geller SA (2003) Cartilaginous metaplasia in calcified diabetic peripheral vascular disease: Morphologic evidence of enchondral ossification. Human Pathol 34:402-407

96. Shroff R, McNair R, Figg N, Skepper J, Schurgers L, Gupta A, Hiorns M, Donald A, Deanfield J, Rees L, Shanahan C (2008) Dialysis Accelerates Medial Vascular Calcification in Part by Triggering Smooth Muscle Cell Apoptosis. Circulation 118:748-1757

97. El-Abbadi M, Pai A, Leaf E, Yang H, Bartley B, Quan K, Ingalls C, Liao H, Giachelli C (2009) Phosphate feeding induces arterial medial calcification in uremic mice: role of serum phosphorus, fibroblast growth factor-23, and osteopontin. Kidney Int 75:1297-1307

98. Nakano-Kurimoto R, Ikeda K, Uraoka M, Nakagawa Y, Yutaka K, Koide M, Takahashi T, Matoba S, Yamada H, Okigaki M, Matsubara H (2009) Replicative senescence of vascular smooth muscle cells enhances the calcification through initiating the osteoblastic transition. Am J Physiology Heart Circ Physiology 297(5):1673-1684

99. Zhu D, Mackenzie N, Millán J, Farquharson C, MacRae V (2011) The appearance and modulation of osteocyte marker expression during calcification of vascular smooth muscle cells. PLoS ONE 6(5): $1-10$

100. Shioi A, Katagi M, Okuno Y, Mori K, Jono S, Koyama H, Nishizawa Y (2002) Induction of bone-type alkaline phosphatase in human vascular smooth muscle cells: roles of tumor necrosis factor-alpha and oncostatin $\mathrm{M}$ derived from macrophages. Circulation Res 91(1):9-16

101. Sheen C, Kuss P, Narisawa S, Yadav M, Nigro J, Wang W, Chhea T, Sergienko E, Kapoor K, Jackson M, Hoylaerts M, Pinkerton A, O’Neill W, Millán J (2015) Pathophysiological role of vascular smooth muscle alkaline phosphatase in medial artery calcification. J Bone Miner Res 30(5):824-836

102. Savinov Y, Salehi M, Yadav C, Radichev I, Millán L, Savinova V (2015) Transgenic overexpression of tissue-nonspecific alkaline phosphatase (TNAP) in vascular endothelium results in generalized arterial calcification. J Am Heart Assoc 4(12):1-13

103. Schoppet M, Shanahan M (2008) Role for alkaline phosphatase as an inducer of vascular calcification in renal failure? Kidney Int 73(9):989-991

104. Murshed M, Harmey D, Millán L, McKee D, Karsenty G (2005) Unique coexpression in osteoblast of broadly expressed genes accounts for the spatial restriction of ECM mineralization to bone. Genes Dev 19(9):1093-1104

105. Watson E, Parhami F, Shin V, Demer L (1998) Fibronectin and collagen I matrixes promote calcification of vascular cells in vitro, whereas collagen IV matrix is inhibitory. Arterioescler Thromb Vasc Biol 18(12):1964-1971

106. Ishimura E, Okuno S, Okazaki H, Norimine K, Yamakawa K, Yamakawa T, Shoji S, Nishizawa Y, Inaba M (2014) Significant association between bone-specific alkaline phosphatase and vascular calcification of the hand arteries in male hemodialysis patients. Kidney Blood Press Res 39:299-307

107. Iba K, Takada J, Yamashita T (2004) The serum level of bonespecific alkaline phosphatase activity is associated with aortic calcification in osteoporosis patients. J Bone Miner Metab 22(6):594-596

108. Lomashvili K, Narisawa S, Millán J, O’Neill W (2014) Vascular calcification is dependent on plasma levels of pyrophosphate. Kidney Int 85(6):1351-1356

109. Joubert P, Ketteler M, Salcedo C, Perelló J (2016) Hypothesis: phytate is an important unrecognised nutrient and potential intravenous drug for preventing vascular calcification. Med Hypotheses 94:89-92

110. Buades J, Sanchís P, Perelló J, Grases F (2016) Plant phosphates, phytate and pathological calcifications in chronic kidney disease. Nefrología 30:1-9

111. Bover J, Ureña Torres P, Górriz J, Lloret M, da Silva I, RuizGarcía C, Chang P, Rodríguez M (2016) Cardiovascular calcifications in chronic kidney disease: potential therapeutic implications. Ballarín J Nefrología, 36(6):597-608

112. Narisawa S, Harmey D, Yadav M, O'Neill W, Hoylaerts M, Millán J (2007) Novel inhibitors of alkaline phosphatase suppress vascular smooth muscle cell calcification. J Bone Miner Res 11:1700-1710

113. Dahl R, Sergienko E, Su Y, Mostofi Y, Yang L, Simao A, Narisawa S, Brown B, Mangravita-Novo A, Vicchiarelli M, Smith L, O’Neill W, Millán J, Cosford N (2009) Discovery and validation of a series of aryl sulfonamides as selective inhibitors of tissuenonspecific alkaline phosphatase (TNAP). J Medicinal Chemistry 21:6919-6925

114. Sidique S, Ardecky R, Su Y, Narisawa S, Brown B, Millán J, Sergienko E, Cosford N (2009) Design and synthesis of pyrazole 
derivatives as potent and selective inhibitors of tissue-nonspecific alkaline phosphatase (TNAP). Bioorg Med Chem Lett 19(1):222-225

115. Sergienko E, Su Y, Chan X, Brown B, Hurder A, Narisawa S, Millán J (2009) Identification and characterization of novel tissue-nonspecific alkaline phosphatase inhibitors with diverse modes of action. J Biomol Screen 7:824-837

116. Chung T, Sergienko E, Millán J (2010) Assay format as a critical success factor for identification of novel inhibitor chemotypes of tissue-nonspecific alkaline phosphatase from high-throughput screening. Molecules 5:3010-3037

117. Sergienko E, Millán J (2010) High-throughput screening of tissue-nonspecific alkaline phosphatase for identification of effectors with diverse modes of action. Nat Protoc 8:1431-1439

118. Linder C, Ek-Rylander B, Krumpel M, Norgård M, Narisawa S, Millán J, Andersson G, Magnusson P (2017) Bone alkaline phosphatase and tartrate-resistant acid phosphatase: potential co-regulators of bone mineralization. Calcif Tissue Int 101(1):92-101

119. Boström K, Tsao D, Shen S, Wang Y, Demer L (2001) Matrix GLA protein modulates differentiation induced by bone morphogenetic protein-2 in C3H10T1/2 cells. J Biol Chem 276(17):14044-14052

120. Rawadi G, Vayssière B, Dunn F, Baron R, Roman-Roman S (2003) BMP-2 controls alkaline phosphatase expression and osteoblast mineralization by a Wnt autocrine loop. J Bone Miner Res 18(10):1842-1853

121. Murali S, Roschger P, Zeitz U, Klaushofer K, Andrukhova O, Erben R (2016) FGF23 regulates bone mineralization in a 1,25(OH)2 D3 and Klotho-Independent manner. J Bone Miner Res 31(1):129-142

122. Murali S, Andrukhova O, Clinkenbeard E, White K, Erben R (2016) Excessive Osteocytic FGF23 Secretion Contributes to Pyrophosphate Accumulation and Mineralization Defect in Hyp Mice. PLoS Biol 14(4):1-24

123. Martin S, Lin H, Ejimadu C, Lee T (2015) Tissue-nonspecific alkaline phosphatase as a target of sFRP2 in cardiac fibroblasts. Am J Physiol Cell Physiol 3:139-147

124. Ali A, Penny C, Paiker J, Psaras G, Ikram F, Crowther N (2006) The effect of alkaline phosphatase inhibitors on intracellular lipid accumulation in preadipocytes isolated from human mammary tissue. Ann Clin Biochem 43:207-213

125. Sardiwal S, Magnusson P, Goldsmith D, Lamb E (2013) Bone alkaline phosphatase in CKD-mineral bone disorder. Am J Kidney Dis $4: 810-822$

126. Cheung C, Tan K, Lam K, Cheung B (2013) The relationship between glucose metabolism, metabolic syndrome, and bonespecific alkaline phosphatase: a structural equation modeling approach. J Clin Endocrinol Metab 98:3856-3863

127. Kaliannan K, Hamarneh R, Economopoulos P, Nasrin S, Moaven O, Patel P, Malo S, Ray M, Abtahi M, Muhammad N, Raychowdhury A, Teshager A, Mohamed M, Moss K, Ahmed R, Hakimian S, Narisawa S, Millán L, Hohmann E, Warren S, Bhan K, Malo S, Hodin A (2013) Intestinal alkaline phosphatase prevents metabolic syndrome in mice. Proc Nat Acad Sci USA 110(17):7003-7008

128. Malo S (2015) A high level of intestinal alkaline phosphatase is protective against Type 2 diabetes mellitus irrespective of obesity. EBioMedicine 2(12):2016-2023

129. Lips P, Duong T, Oleksik A, Black D, Cummings S, Cox D, Nickelsen T (2001) A global study of vitamin D status and parathyroid function in postmenopausal women with osteoporosis: baseline data from the multiple outcomes of raloxifene evaluation clinical trial. J Clin Endocrinol Metab 86:3008

130. Thomas M, Lloyd-Jones D, Thadhani R, Shaw A, Deraska D, Kitch B, Vamvakas E, Dick I, Prince R, Finkelstein J (1998)
Hypovitaminosis D in medical inpatients. N Eng J Med 338:777-783

131. Wolf M, Shah A, Gutierrez O, Ankers E, Monroy M, Tamez H, Steele D, Chang Y, Camargo C, Tonelli M, Thadhani R (2007) Vitamin D levels and early mortality among incident hemodialysis patients. Kidney Int 72(8):1004-1013

132. Belozeroff V, Goodman W, Ren L, Kalantar-Zadeh K (2009) Cinacalcet lowers serum alkaline phosphatase in maintenance hemodialysis patients. Clin J Am Soc Nephrol 4(3):673-679

133. Llach F, Yudd M (2001) Paricalcitol in dialysis patients with calcitriol-resistant secondary hyperparathyroidism. Am J Kidney Dis 38(5 Suppl 5):45-50

134. Palmer S, McGregor D, Macaskill P, Craig J, Elder G, Strippoli F (2007) Meta-analysis: vitamin D compounds in chronic kidney disease. Ann Intern Med 147(12):840-853

135. Coyne D, Andress D, Amdahl M, Ritz E, de Zeeuw D (2013) Effects of paricalcitol on calcium and phosphate metabolism and markers of bone health in patients with diabetic nephropathy: results of the VITAL study. Nephrol Dial Transplant 28(9):2260-2268

136. Lomashvili K, Khawandi W, O’Neill C (2005) Reduced plasma pyrophosphate levels in hemodialysis patients. J Am Soc Nephrol 16(8):2495-2500

137. Makar H, Sawires K, Farid M, Ali M, Schaalan M (2010) Effect of high-flux versus low-flux dialysis membranes on parathyroid hormone. Iran J Kidney Dis 4(4):327-332

138. López-González A, Grases F, Perello J, Tur F, Costa A, Monroy N, Mari B, Vicente T (2010) Phytate levels and bone parameters: a retrospective pilot clinical trial. Front Biosci 2:1093-1098

139. Grases F, Sanchis P, Perello J, Isern B, Prieto R, FernandezPalomeque C, Fiol M, Bonnin O, Torres J (2006). Phytate (Myoinositol hexakisphosphate) inhibits cardiovascular calcifications in rats. Front Biosci, (11): 136-142

140. Perelló J, Salcedo C, Joubert P, Canals A, Ferrer M (2015) Firsttime-in-human phase 1 clinical trial in healthy volunteers with SNF472, a novel inhibitor of vascular calcification. Nephrol Dial Transplant 30(suppl 3):iii592 (abstract)

141. Jansen R, Duijst S, Mahakena S, Sommer D, Szeri F, Váradi A, Plomp A, Bergen A, Oude R, Borst P, van de Wetering K (2014) ABCC6-mediated ATP secretion by the liver is the main source of the mineralization inhibitor inorganic pyrophosphate in the systemic circulation-brief report. Arterioscler Thromb Vasc Biol 34(9):1985-1989

142. Pomozi V, Brampton C, Szeri F, Dedinszki D, Kozák E, van de Wetering K, Hopkins H, Martin L, Váradi A Le Saux (2016) Functional rescue of ABCC6 deficiency by 4-Phenylbutyrate therapy reduces dystrophic calcification in Abcc6-/- Mice. J Invest Dermatol 5:1-25

143. Albright R, Stabach P, Cao W, Kavanagh D, Mullen I, Braddock A, Covo M, Tehan M, Yang G, Cheng Z, Bouchard K, Yu Z, Thorn S, Wang X, Folta-Stogniew E, Negrete A, Sinusas A, Shiloach J, Zubal G, Madri J, De La Cruz E, Braddock D (2015) ENPP1-Fc prevents mortality and vascular calcifications in rodent model of generalized arterial calcification of infancy. Albright Nature Commun 6:1-32

144. Ho A, Johnson M, Kingsley D (2000) Role of the mouse ank gene in control of tissue calcification and arthritis. Science 289(5477):265-270

145. Wang W, Xu J, Du B, Kirsch T (2005) Role of the progressive ankylosis gene (ank) in cartilage mineralization. Molecular Cellular Biology 25(1):312-323

146. Gurley K, Chen H, Guenther C, Nguyen E, Rountree R, Schoor M, Kingsley D (2006) Mineral formation in joints caused by complete or joint-specific loss of ANK function. J Bone Miner Res 21(8):1238-1247 
147. Villa-Bellosta R, Rivera-Torres J, Osorio F, Acín-Pérez R, Enriquez J, López-Otín C, Andrés V (2013) Defective extracellular pyrophosphate metabolism promotes vascular calcification in a mouse model of Hutchinson-Gilford progeria syndrome that is ameliorated on pyrophosphate treatment. Circulation 127(24):2442-2451

148. De Oliveira R, Louvet L, Riser B, Barreto F, Benchitrit J, Rezg R, Poirot S, Jorgetti V, Drüeke T, Massy Z (2015) Peritoneal delivery of sodium pyrophosphate blocks the progression of pre-existing vascular calcification in uremic apolipoprotein-E knockout mice. Calcif Tissue Int 97(2):179 - 92

149. Marqués S, Buchet R, Popowycz F, Lemaire M, Mebarek S (2016) Synthesis of benzofuran derivatives as selective inhibitors of tissue-nonspecific alkaline phosphatase: effects on cell toxicity and osteoblast-induced mineralization. Bioorg Med Chem Lett 26(5):1457-1459

150. Picaud S, Wells C, Felletar I, Brotherton D, Martin S, Savitsky P, Diez-Dacal B, Philpott M, Bountra C, Lingard H, Fedorov O, Müller S, Brennan E, Knapp S, Filippakopoulos P (2013) RVX-208, an inhibitor of BET transcriptional regulators with selectivity for the second bromodomain. Proc Nat Acad Sci USA 110(49):19754-19759

151. Gilham D, Wasiak S, Tsujikawa L, Halliday C, Norek K, Patel R, Kulikowski E, Johansson J, Sweeney M, Wong N (2016) RVX208, a BET-inhibitor for treating atherosclerotic cardiovascular disease, raises ApoA-I/HDL and represses pathways that contribute to cardiovascular disease. Atheroscler 247:48-57

152. Kalantar-Zadeh $\mathrm{K}$ et al (2015) Alkaline phosphatase lowering by selective bet inhibition, a novel mechanism for mace reduction in high risk cvd, diabetes and CKD patients - a post-hoc analysis of phase 2b studies with RVX-208. J Am Soc Nephrol 26:227A

153. Wong N, Kalantar-Zadeh K, Kulikowski E, Wasiak S, Gilham D, Halliday C, Sweeney M, Johansson J (2016) SP071 Apabetalone (RVX-208), a selective bromodomain and extra-terminal (BET) protein inhibitor, decreases abundance and activity of complement proteins in vitro, in mice and in clinical studies. Nephrol Dial Transplant 31(suppl 1):i109

154. Kausik R (Estimated study completion data October 2018). Phase A, Multi-Center III, Double-Blind, Randomized, Parallel Group, Placebo-Controlled Clinical Trial in High-Risk Type 2 Diabetes Mellitus (T2DM) Subjects With Coronary Artery Disease (CAD) to Determine Whether Bromodomain Extraterminal Domain (BET) Inhibition Treatment With RVX000222 Increases. the Time to Major Adverse Cardiovascular Events (MACE)

155. Gasque C, Foster L, Kuss P, Yadav C, Liu J, Kiffer-Moreira T, van Elsas A, Hatch N, Somerman J, Millán L (2015)
Improvement of the skeletal and dental hypophosphatasia phenotype in Alpl-/- mice by administration of soluble (non-targeted) chimeric alkaline phosphatase. Bone 72:137-147

156. Peters E, Mehta L, Murray T, Hummel J, Joannidis M, Kellum A Arend J, Pickkers P (2016) Study protocol for a multicentre randomised controlled trial: Safety, Tolerability, efficacy and quality of life Of a human recombinant alkaline Phosphatase in patients with sepsis-associated Acute Kidney Injury (STOP-AKI). BMJ Open 6(9):e012371

157. Peters E, Geraci S, Heemskerk S, Wilmer J, Bilos A, Kraenzlin B, Gretz N, Pickkers P, Masereeuw R (2015) Alkaline phosphatase protects against renal inflammation through dephosphorylation of lipopolysaccharide and adenosine triphosphate. Br J Pharmacol 172(20):4932-4945

158. Peters E, Ergin B, Kandil A, Gurel-Gurevin E, van Elsas A, Masereeuw R, Pickkers P, Ince C (2016) Effects of a human recombinant alkaline phosphatase on renal hemodynamics, oxygenation and inflammation in two models of acute kidney injury. Toxicol Appl Pharmacol 313:88-96

159. Ghosh S, Gehr W, Ghosh S (2014) Curcumin and chronic kidney disease (CKD): major mode of action through stimulating endogenous intestinal alkaline phosphatase. Molecules 19(12):20139-20156

160. Ghosh S, Bie J, Wang J, Ghosh S (2014) Oral supplementation with non-absorbable antibiotics or curcumin attenuates western diet-induced atherosclerosis and glucose intolerance in LDLR-/mice-role of intestinal permeability and macrophage activation. PLoS One 9(9):e108577: 1-9

161. Millán L, Whyte P (2016) Alkaline Phosphatase and Hypophosphatasia. Calcif Tissue Int 98(4):398-416

162. Sardiwal S, Gardham C, Coleman A, Stevens P, Delaney M, Lamb E (2012) Bone-specific alkaline phosphatase concentrations are less variable than those of parathyroid hormone in stable hemodialysis patients. Kidney Int 82(1):100-105

163. Garrett G, Sardiwal S, Lamb E, Goldsmith D (2013) PTH-a particularly tricky hormone: why measure it at all in kidney patients? Clin J Am Soc Nephrol 8(2):299-312

164. Sprague S, Moe S (2013) The Case for Routine Parathyroid Hormone Monitoring. Clin J Am Soc Nephrol 8(2):313-318

165. Gardham C, Stevens E, Delaney P, LeRoux M, Coleman A, Lamb J (2010) Variability of parathyroid hormone and other markers of bone mineral metabolism in patients receiving hemodialysis. Clin J Am Soc Nephrol 5(7):1261-1267 